Микола Миколайович Биченок (әоктор технічних наук, с.н.с.)

Національний університет оборони Украйни імені Івана Черняховського, Киӥв, Украӥна

\title{
ОЦІНЮВАННЯ РИЗИКІВ ЖИТТЄДІЯЛЬНОСТІ ЛЮДИНИ І НАСЕЛЕННЯ У ПРИРОДНО-ТЕХНОГЕННОМУ СЕРЕДОВИЩІ В УМОВАХ ОСОБЛИВОГО ПЕРІОДУ
}

Зростання антропогенного впливу на навколишне середовище разом з інтенсивним використанням природних ресурсів зумовлюють стійку тенденцію до збільшення негативних наслідків для життєдіяльності населення від надзвичайних ситуачій природного та техногенного походження на території Украӥни. Крім того, в умовах економічної скрути, а також гібрідної війни на сході Украӥни з боку РФ зменшуються витрати на впровадження новітніх технологій, модернізацію виробничих процесів і ремонтно-профілактичні заходи, зростає кількість зношеного обладнання, знижується рівень технологічної дисичиліни.

У даній роботі на основі узагальнення досвіду оиінювання та прогнозування ризиків виникнення надзвичайних ситуацій у різних регіонах Украӥни, в першу чергу на територіях підвищеної природної $i$ техногенної небезпеки, розробляються методологічні основи оиінки ризиків життєдіяльності в цุих умовах.

Ключові слова: надзвичайні ситуації, ризики життєдіяльності, техногенні і природні загрози.

\section{Вступ}

Обмежений обсяг ресурсів для проведення захисних заходів визначає необхідність їхнього використання для нейтралізації загроз на найбільш пріоритетних напрямах. Серед найактуальніших природних загроз в умовах України проявляються небезпечні екзогенні геологічні процеси (НЕГП), насамперед підтоплення, зсуви, карст, просідання лесових грунтів [1,2].

Що стосується техногенних загроз, то найактуальнішими для умов України можна вважати аварії на хімічно небезпечних об'єктах (XHO) [ 3,4$]$.

Хімічні, нафтохімічні i нафтопереробні виробництва в Україні характеризуються зношенням основних фондів, а також погіршенням інженерно-геологічних умов промислових майданчиків внаслідок природної і техногенної активізації НЕГП. Упродовж останніх десятиріч відбувається активний процес зниження міцності верхньої зони порід внаслідок порушення режиму їхнього водо- та теплообміну, геохімічних параметрів ландшафтів та гідрогеохімічного режиму зони активного водообміну.

Значна частина потенційно небезпечних об'єктів в Україні, в тому числі ХНО, розташована в зонах імовірної активізації природних i техногенних НЕГП. Площинний характер розвитку більшості НЕГП суттєво збільшує ризики виникнення аварій на ХНО за рахунок деформацій i руйнувань відповідальних конструктивних елементів.

Постановка проблеми. В умовах особливого періоду, враховуючи військові дії на сході нашої країни, актуальною проблемою $\epsilon$ оцінювання ризиків життєдіяльності людини і населення від впливу природних і техногенних загроз. Ці загрози потебують оперативного оцінювання і адекватного реагування, оскільки їх наслідки усугубляються під дією військових факторів.

Аналіз останніх досліджень і публікацій. Розробкою методів оцінювання природних i техногенних ризиків життєдіяльності займалось багато вчених, зокрема, Б.М. Данілишин [1] і С.О. Яковлев [2] розробляли методи оцінювання природних ризиків. Техногенні ризики досліджувались С.П. Іванютою [3], А.Б. Качинським [6] та ін.

Але у розглянутих авторів питання, які пов'язані 3 обгрунтуванням комплексного оцінювання ризиків життєдіяльності у природнотехногенному середовищі не розглядались.

Метою статті $є$ розробка моделей і методів комплексного оцінювання ризиків життєдіяльності в умовах негативних природних і техногенних загроз. 


\section{Виклад основного матеріалу дослідження}

Регіональна природно-техногенна активізація НЕГП на сучасному етапі функціонування численних просторово розосереджених техногенно-геологічних систем "техногенний об'єкт - геологічне середовище" зумовлює двоєдину структуру формування ризиків життєдіяльності в зонах впливу потенційно небезпечних об'єктів, у першу чергу хімічно небезпечних:

погіршення інженерно-геологічної стійкості середовища внаслідок природно-техногенної активізації НЕГП;

локальний вплив потенційно небезпечних об'єктів на зміни інженерно-геологічних показників порід підгрунтя (міцність, агресивність до будівельних конструкцій та ін.).

В цілому спостерігається суттєве відхилення інженерних параметрів промислових майданчиків від початкових проектних, що зумовлює додаткові деформації технологічно важливих споруд, водота теплопостачальних систем, порід підгрунтя, фундаментів та ін. [ 2 ]

На підприємствах хімічного комплексу понад 900 будівель і споруд на контрольованому періоді не мали капітальних ремонтів, близько 125 будівель i споруд не відповідають вимогам будівельних норм і правил, понад 40 - знаходяться в аварійному стані. Все це суттєво підвищує негативний вплив НЕГП i збільшує ризик аварійних ситуацій.

Внесок природних факторів у формування ризику можна враховувати за експертною оцінкою шляхом введення відповідних підвищуючих коефіцієнтів, оскільки вплив цих процесів на зростання ризику аварії відбувається за кумулятивною моделлю взаємодії. Значення підвищуючого коефіцієнта за рахунок негативних змін інженерно-геологічних умов для різних типів прояву цих процесів обгрунтовано на основі експертної оцінки: при просіданні $\mathrm{K}^{\mathrm{p}}=2$; при підтопленні $\mathrm{K}^{\mathrm{f}}=5$; при комплексній дії підтоплення і просідання $\mathrm{K}^{\mathrm{K}}=5 * 2=10$.

Ймовірність прояву НЕГП у природному режимі їхнього розвитку $\mathrm{P}_{1}\left(\mathrm{H}_{1}\right)$ залежить від двох основних чинників, що впливають на іiі формування: просторової ураженості території об'єктами НЕГП $\mathrm{K}_{\mathrm{s}}$ та часової динаміки розвитку об'єктів НЕГП $\mathrm{K}_{\mathrm{d}}$ як частоти їхньої активізації за певний проміжок часу (випадків/рік). Таким чином, річна імовірність природного прояву НЕГП на території оцінки визначатиметься

$$
\mathrm{P}_{1}\left(\mathrm{H}_{1}\right)=\mathrm{K}_{\mathrm{s}} * \mathrm{~K}_{\mathrm{d}},
$$

де $\mathrm{K}_{\mathrm{s}}$ - просторова ураженість території НЕГП;

$\mathrm{K}_{\mathrm{d}}$ - часова динаміка розвитку НЕГП.
3 урахуванням зазначенного природний ризик життєдіяльності на території можливого прояву НЕГП оцінюється за співвідношенням

$$
\mathrm{R}_{1}\left(\mathrm{H}_{1}\right)=\mathrm{P}_{1}\left(\mathrm{H}_{1}\right) * \mathrm{~V}_{1}\left(\mathrm{H}_{1}\right) * \mathrm{~K}_{1}\left(\mathrm{H}_{1}\right) * \mathrm{~N} \text {, }
$$

де $\mathrm{R}_{1}\left(\mathrm{H}_{1}\right)$ - колективний ризик життєдіяльності (втрати здоров'я чи загибелі населення) на даній території в результаті активізації екзогенних геологічних процесів (чол/рік);

$\mathrm{P}_{1}\left(\mathrm{H}_{1}\right)$ - імовірність прояву НЕГП на досліджуваній території (випадків/рік);

$\mathrm{V}_{1}\left(\mathrm{H}_{1}\right)$ - уразливість території від прояву НЕГП, що визначається відношенням ураженої частини території до іiі загальної площі (частки одиниці);

$\mathrm{K}_{1}\left(\mathrm{H}_{1}\right)$ - просторова уразливість населення (частки одиниці);

$\mathrm{N}$ - чисельність населення на території дослідження (чол.).

Під аварією з викидом небезпечних хімічних речовин розуміється надзвичайна ситуація техногенного характеру, що сталася на ХНО внаслідок виробничих, конструктивних, технологічних чи експлуатаційних причин або від зовнішніх впливів і призвела до пошкодження технологічного обладнання, пристроїв, споруд, транспортних засобів 3 формуванням зони хімічного зараження, яка становить реальну загрозу для здоров'я і життєдіяльності людей [ 4 ]. Ризик життєдіяльності в цій зоні визначається як вірогідність загибелі чи захворювання людей внаслідок отруєння.

Оцінювання ризиків життєдіяльності від можливих аварій на ХНО базується на результатах прогнозування наслідків аварійного викиду небезпечних хімічних речовин, що здійснюється 3 урахуванням: обсягів викиду та метеорологічних умов для визначення параметрів зони хімічного зараження і відпрацювання необхідних дій у цій зоні.

Прогнозування наслідків аварійного викиду передбачає відповідно до [ 7 ] визначення таких параметрів можливої зони хімічного зараження:

кут сектора зони з урахуванням стійкості напрямку вітрового потоку та швидкості вітру;

глибина зони R, км;

розрахункова (можлива) площа зони $\mathrm{S}, \mathrm{\kappa м}^{2}$;

кількість населення в зоні (визначається за кількістю мешканців населених пунктів, що потрапляють у цю зону) $\mathrm{N}_{2}$, чол.;

площа максимально можливого поширення токсичної хмари $\mathrm{S}_{\max }=\pi * \mathrm{R}^{2}, \mathrm{\kappa м}^{2}$;

Імовірність виникнення аварії $\mathrm{P}_{2}\left(\mathrm{H}_{2}\right)$ на ХHO 3 викидом токсичних речовин визначається як середньорічна частота хімічно небезпечних аварій, від яких можуть постраждати (захворіти або загинути) люди внаслідок ураження

$$
\mathrm{P}_{2}\left(\mathrm{H}_{2}\right)=\mathrm{N}_{\mathrm{a}} / \mathrm{N}_{\mathrm{h}}
$$


де $\mathrm{N}_{\mathrm{a}}$ - кількість аварій на ХНО 3 викидом небезпечних хімічних речовин, внаслідок яких можуть постраждати люди;

$\mathrm{N}_{\mathrm{h}}$ - загальна кількість XНО на території дослідження.

3 урахуванням цього максимально можливий колективний техногенний ризик життєдіяльності $\mathrm{R}_{2}\left(\mathrm{H}_{2}\right)$ в умовах можливої аварії на заданому ХНO в межах прогнозованої площі зони визначається за формулою

$$
\mathrm{R}_{2}\left(\mathrm{H}_{2}\right)=\mathrm{P}_{2}\left(\mathrm{H}_{2}\right) * \mathrm{~V}_{2}\left(\mathrm{H}_{2}\right) * \mathrm{~K}_{2}\left(\mathrm{H}_{2}\right) * \mathrm{~N}
$$

де $\mathrm{R}_{2}\left(\mathrm{H}_{2}\right)$ - колективний ризик втрати здоров'я чи загибелі населення на даній території при можливій аварії на XНО з викидом небезпечних хімічних речовин (чол/рік);

$\mathrm{P}_{2}\left(\mathrm{H}_{2}\right)$ - ймовірність виникнення аварії на ХНО (випадків/рік);

$\mathrm{V}_{2}\left(\mathrm{H}_{2}\right)$ - уразливість території від можливої аварії на ХНО (частки одиниці);

$\mathrm{K}_{2}\left(\mathrm{H}_{2}\right)$ - просторова уразливість населення (частки одиниці);

$\mathrm{N}$ - чисельність населення на території дослідження (чол.).

Уразливість території від можливої аварії на $\mathrm{XHO} \mathrm{V}_{2}\left(\mathrm{H}_{2}\right)$ визначається відношенням площі ураженої частини території до ії загальної площі

$$
\mathrm{V}_{2}\left(\mathrm{H}_{2}\right)=\mathrm{S}_{2} / \mathrm{S} \text {, }
$$

де $\mathrm{S}_{2}$ - площа зони, що формується в результаті аварії з викидом небезпечних хімічних речовин $\left(\mathrm{KM}^{2}\right)$;

$\mathrm{S}$ - площа території дослідження:області, району, промислового майданчика тощо $\left(\right.$ км² $^{2}$.

Просторова ураженість населення $\mathrm{K}_{2}\left(\mathrm{H}_{2}\right)$ визначається співвідношенням кількості населення, що перебуває в зонах можливого ураження, до чисельності населення на території дослідження

$$
\mathrm{K}_{2}\left(\mathrm{H}_{2}\right)=\mathrm{N}_{2} / \mathrm{N} \text {, }
$$

де $\mathrm{N}_{2}$ - чисельність населення, що перебуває в зонах можливого ураження (чол.);

$\mathrm{N}$ - чисельність населення на території дослідження (чол.).

Вплив регіонально розповсюджених екзогенних геологічних процесів у рамках природно-техногенної системи “хімічно небезпечний об'єкт - геологічне середовище” зумовлює формування техногенно-природного ризику, який визначається 3 урахуванням коефіцієнта впливу відповідних НЕГП на ХНО.

\section{Комплексне оцінювання ризиків життедіяльності}

Метод комплексного оцінювання природнотехногенних ризиків життєдіяльності, обумовлених спільною дією небезпечних природних i техногенних чинників, що проявляються у вигляді НЕГП та аварій на ХНО, розроблено виходячи з наступних міркувань.
При функціонуванні складної техногенногеологічної системи «хімічно небезпечний об'єкт геологічне середовище» можливі різні небажані події природного $\left(\mathrm{H}_{1}\right)$ i техногенного $\left(\mathrm{H}_{2}\right)$ походження, які характеризуються різними за своїми масштабами і негативними наслідками для життєдіяльності населення.

Вважається, що будь-які з цих небажаних подій $\mathrm{H}_{1}$ i $\mathrm{H}_{2}$ мають певні природні чи техногенні прояви, а саме $\mathrm{H}_{1}$ - активізацію небезпечних екзогенних геологічних процесів, $\mathrm{H}_{2}$ - аварії на ХНО 3 викидом токсичних речовин. Причому прояв однієї 3 цих подій не виключає прояву іншої, тобто на потенційно небезпечній території може відбутися як активізація НЕГП, так і хімічно небезпечна аварія з викидом токсичних речовин.

За таких умов будемо вважати, що функціонування природно-техногенної системи може призвести до виникнення незалежних чи сумісних негативних подій природного i техногенного походження у вигляді проявів НЕГП та аварій на ХНО.

Оцінювання природно-техногенного ризику життєдіяльності, який враховує комплексну дію природних і техногенних факторів, базується на визначенні комбінованої імовірності прояву подій природного $\left(\mathrm{H}_{1}\right)$ і техногенного $\left(\mathrm{H}_{2}\right)$ походження, що представлені відповідно у вигляді активізації НЕГП та аварій на ХНО. Припускаючи, що ці події $\epsilon$ незалежними, комбінована імовірність їхньої реалізації на даній території визначається за законом складання ймовірностей незалежних подій [8]

$$
\mathrm{P}_{3}\left(\mathrm{H}_{3}\right)=\mathrm{P}_{1}\left(\mathrm{H}_{1}\right)+\mathrm{P}_{2}\left(\mathrm{H}_{2}\right)-\mathrm{P}_{1}\left(\mathrm{H}_{1}\right) * \mathrm{P}_{2}\left(\mathrm{H}_{2}\right),
$$

де $\mathrm{P}_{3}\left(\mathrm{H}_{3}\right)$ - комбінована імовірність виникнення подій природного i техногенного походження (прояву НЕГП та аварії на ХНО);

$\mathrm{P}_{1}\left(\mathrm{H}_{1}\right)$ - імовірність прояву НЕГП;

$\mathrm{P}_{2}\left(\mathrm{H}_{2}\right)$ - імовірність виникнення аварії на ХНО.

Таким чином, оцінювання природнотехногенного ризику життєдіяльності можна здійснювати за наступним співвідношенням:

$$
\mathrm{R}_{3}\left(\mathrm{H}_{3}\right)=\mathrm{P}_{3}\left(\mathrm{H}_{3}\right) * \mathrm{~V}_{3}\left(\mathrm{H}_{3}\right) * \mathrm{~K}_{3}\left(\mathrm{H}_{3}\right) * \mathrm{~N},
$$

де $\mathrm{R}_{3}\left(\mathrm{H}_{3}\right)$ - комплексний ризик загибелі чи втрати здоров'я населення на даній території в умовах можливих аварій на ХНО i проявів НЕГП (чол/рік);

$\mathrm{P}_{3}\left(\mathrm{H}_{3}\right)$ - комбінована імовірність виникнення аварії на ХНО і прояву НЕГП;

$\mathrm{V}_{3}\left(\mathrm{H}_{3}\right)$ - уразливість території (частки одиниці);

$\mathrm{K}_{3}\left(\mathrm{H}_{3}\right)$ - просторова уразливість населення (частки одиниці);

$\mathrm{N}$ - чисельність населення на території дослідження (чол.).

Пропонований метод комплексного оцінювання ризиків життєдіяльності розглядається 
далі на методичному прикладі можливої аварії на Мелітопольському ДКП “Водоканал”. Для моделювання використано такі вхідні параметри:

вид небезпечної хімічної речовини - хлор;

обсяг викиду - 300 т;

температура повітря - $+20^{0} \mathrm{C}$;

напрямок вітру - північний;

швидкість вітру - 3 м/с;

ступінь вертикальної стійкості повітря ізотермія;

фактори впливу природної небезпеки на ХНО підтоплення і просідання лесових грунтів.

Відповідно до методики [ 7 ] визначаються параметри можливої зони хімічного зараження:

кут сектора зони 3 урахуванням стійкості напрямку вітрового потоку і швидкості вітру $\alpha=$ $45^{0}$;

глибина зони $\mathrm{R}=26,8$ км;

можлива площа зони $\mathrm{S}=\pi^{*} \mathrm{R}^{2} * 45^{0} / 360^{0}=281,8$ $\mathrm{KM}^{2}$;

чисельність населення в зоні $\mathrm{N}=18722$ чол.;

площа максимально можливого поширення токсичної хмари $\mathrm{S}_{\max }=\pi * \mathrm{R}^{2}=2255$ км$^{2}$.

\section{Оцінювання техногенного}

ризику

життсдіяльності в умовах можливих аварій на ХНО здійснюється за наведеною вище формулою:

$$
\mathrm{R}_{2}\left(\mathrm{H}_{2}\right)=\mathrm{P}_{2}\left(\mathrm{H}_{2}\right) * \mathrm{~V}_{2}\left(\mathrm{H}_{2}\right) * \mathrm{~K}_{2}\left(\mathrm{H}_{2}\right) * \mathrm{~N} \text {. }
$$

Імовірність виникнення аварії на ХНО 3 викидом токсичних речовин визначається як середньорічна частота хімічно небезпечних аварій у заданому регіоні, від яких можуть постраждати (захворіти або загинути) люди внаслідок отруєння. За даними МНС України у 2005 році зареєстровано 4 аварії на ХНО 3 викидом токсичних речовин, унаслідок яких постраждало 6 чоловік [4] загальна кількість ХНО в Україні складає 1575 об'єктів.

Таким чином, статистична ймовірність аварії $\mathrm{P}_{2}$ $\left(\mathrm{H}_{2}\right)$ на ХНО 3 викидом токсичних речовин, які становить загрозу для життєдіяльності населення, визначається співвідношенням:

$$
\mathrm{P}_{2}\left(\mathrm{H}_{2}\right)=4 / 1575=2,5 * 10^{-3} \text {. }
$$

Уразливість території $\mathrm{V}_{2}\left(\mathrm{H}_{2}\right)$ від можливої аварії на ХНО визначається відношенням ураженої частини території Запорізької області до іiі загальної площі

$$
\mathrm{V}_{2}\left(\mathrm{H}_{2}\right)=281,8 / 27200=0,01036 .
$$

Просторова уразливість населення регіону $\mathrm{K}_{2}$ $\left(\mathrm{H}_{2}\right)$ в умовах можливої аварії на ХНO визначається співвідношенням кількості населення в зоні можливого ураження (оцінюється засобами ГІС) до загальної кількості населення Запорізької області

$$
\mathrm{K}_{2}\left(\mathrm{H}_{2}\right)=71781 / 1929200=0,0372 .
$$

Таким чином, індивідуальний $(\mathrm{N}=1)$ техногенний ризик життєдіяльності в регіоні при повномасштабному прояві можливої аварії становитиме

$$
\begin{gathered}
\mathrm{R}_{2}\left(\mathrm{H}_{2}\right)=\mathrm{P}_{2}\left(\mathrm{H}_{2}\right) * \mathrm{~V}_{2}\left(\mathrm{H}_{2}\right) * \mathrm{~K}_{2}\left(\mathrm{H}_{2}\right)=2,5 * 10^{-3} * \\
0,01036 * 0,0372=9,63 * 10^{-7} \text { чол/piк. }
\end{gathered}
$$

Природний ризик життсдіяльності на території можливого прояву НЕГП оцінюється за вище наведеним співвідношенням:

$$
\mathrm{R}_{1}\left(\mathrm{H}_{1}\right)=\mathrm{P}_{1}\left(\mathrm{H}_{1}\right) * \mathrm{~V}_{1}\left(\mathrm{H}_{1}\right) * \mathrm{~K}_{1}\left(\mathrm{H}_{1}\right) * \mathrm{~N} .
$$

Імовірність прояву НЕГП у природному режимі їхнього розвитку $\mathrm{P}_{1}\left(\mathrm{H}_{1}\right)$ залежить від двох головних чинників:

просторової уразливості території $\mathrm{V}_{1}\left(\mathrm{H}_{1}\right)$ об'єктами НЕГП (частина сумарної площі зон підтоплення і просідань $\mathrm{S}_{1}$ у межах площі області $\mathrm{S}): \mathrm{V}_{1}\left(\mathrm{H}_{1}\right)=\mathrm{S}_{1} / \mathrm{S}$.

часової динаміки розвитку $\mathrm{K}_{\mathrm{t}}$ об'єктів НЕГП як частоти їхньої активізації за визначений проміжок часу T (років), унаслідок впливу швидко змінюваних гідрометеорологічних факторів активізація відбувається із середньою частотою 1 раз від 3-4 до 11-30 років:

$\mathrm{K}_{\mathrm{t}}=1 / \mathrm{T}=1 /(3-4) \div 1 /(11-30) \approx 3 * 10^{-1} \div 3 * 10^{-2}, 1 /$ piк.

Просторова уразливість території Запорізької області процесами підтоплення визначається наступним чином:

$$
\mathrm{V}_{1}\left(\mathrm{H}_{1}\right)=96,3 / 27200=0,00354 .
$$

Коефіцієнт часової динаміки розвитку процесів підтоплення за експертною оцінкою спеціалістів Державної геологічної служби України приймається $\mathrm{K}_{\mathrm{t}}=0,3$, що відповідає середньостатистичній частоті активізації цих процесів: 1 раз у 3 роки.

3 урахуванням цього визначається ймовірність прояву процесів підтоплення у можливій зоні хімічного зараження

$$
\mathrm{P}_{1}\left(\mathrm{H}_{1}\right)=\mathrm{V}_{1}\left(\mathrm{H}_{1}\right) * \mathrm{~K}_{\mathrm{t}}=0,00354 * 0,3=0,00106 .
$$

Просторова уразливість населення $\mathrm{K}_{1}\left(\mathrm{H}_{1}\right)$ визначається співвідношенням кількості населення на територіях можливого прояву НЕГП (оцінюється засобами ГІС) до загальної кількості населення регіону:

$$
\mathrm{K}_{2}\left(\mathrm{H}_{2}\right)=463008 / 1929200=0,24 .
$$

Таким чином, індивідуальний $(\mathrm{N}=1)$ природний ризик життєдіяльності на території можливого прояву НЕГП становитеме:

$$
\begin{gathered}
\mathrm{R}_{1}\left(\mathrm{H}_{1}\right)=\mathrm{P}_{1}\left(\mathrm{H}_{1}\right) * \mathrm{~V}_{1}\left(\mathrm{H}_{1}\right) * \mathrm{~K}_{1}\left(\mathrm{H}_{1}\right)= \\
=0,0012 * 0,00354 * 0,24=9,02 * 10^{-7} \text { чол/piк. }
\end{gathered}
$$

Оцінювання природно-техногенного ризику життєдіяльності, який враховує комплексну дію природних і техногенних факторів, базується на визначенні комбінованої ймовірності прояву подій природного $\left(\mathrm{H}_{1}\right)$ i техногенного походження $\left(\mathrm{H}_{2}\right)$, що представлені відповідно у вигляді активізації НЕГП та аварій на ХНО. Припускаючи, що ці події $є$ незалежними, комбінована ймовірність їхньої реалізації на даній території визначається за 
відомим законом складання ймовірностей незалежних подій [ 8 ]

$$
\begin{gathered}
\mathrm{P}_{3}\left(\mathrm{H}_{3}\right)=\mathrm{P}_{1}\left(\mathrm{H}_{1}\right)+\mathrm{P}_{2}\left(\mathrm{H}_{2}\right)-\mathrm{P}_{1}\left(\mathrm{H}_{1}\right) * \mathrm{P}_{2}\left(\mathrm{H}_{2}\right)= \\
=2,5 \cdot 10^{-3}+1,06 * 10^{-3}-2,5 * 10^{-3} * 1,06 * 10^{-3} \\
=3,55 \cdot 10^{-3} 1 / \text { piк. }
\end{gathered}
$$

Оцінювання природно-техногенного ризику життєдіяльності здійснюється за співвідношенням:

$$
\mathrm{R}_{3}\left(\mathrm{H}_{3}\right)=\mathrm{P}_{3}\left(\mathrm{H}_{3}\right) * \mathrm{~V}_{3}\left(\mathrm{H}_{3}\right) * \mathrm{~K}_{3}\left(\mathrm{H}_{3}\right) * \mathrm{~N} \text {, }
$$

де $\mathrm{R}_{3}\left(\mathrm{H}_{3}\right)$ - комплексний ризик загибелі чи втрати здоров'я населення на даній території в умовах можливих аварій на ХНО та проявів НЕГП (чол/рік);

$\mathrm{P}_{3}\left(\mathrm{H}_{3}\right)$ - комбінована ймовірність виникнення аварії на ХНО та прояву НЕГП;

$\mathrm{V}_{3}\left(\mathrm{H}_{3}\right)$ - уразливість території (частки одиниці);

$\mathrm{K}_{3}\left(\mathrm{H}_{3}\right)$ - просторова уразливість населення (частки одиниці);

$\mathrm{N}$ - чисельність населення на території дослідження (чол.).

\section{Лimepamypa}

1 Данилишини Б.М. Природно-техногенні катастрофи: проблеми економічного аналізу та управління.-К.: НІЧЛАВА, 2001.-260 с. 2. Биченок М.М., Іванюта С.П., Яковлев Є.О., Про вплив екзогенних геологічних процесів на рівень техногенних ризиків життєдіяльності // Збірник наукових праць УкрДІГРІ 2006- №1.- С..85-91 3. Буравлев Є.П., Гетман В.В. Управління техногенною безпекою України. - К.: ІПНБ, 2006. - 248 с. 4. Національна доповідь про стан техногенної та природної безпеки в Україні у 2006 р. - К.: ДП «Чорнобильінтерінформ, 2007. - 236 с.5 Іванюта С.П. ГІС реалізація оцінки ризику життедіяльності від аварій на хімічно небезпечних об'єктах. // Екологія і ресурси. -
3 урахуванням викладеного індивідуальний $(\mathrm{N}=1)$ природно-техногенний ризик життєдіяльності

$$
\begin{gathered}
\mathrm{R}_{3}\left(\mathrm{H}_{3}\right)=\mathrm{P}_{3}\left(\mathrm{H}_{3}\right) * \mathrm{~V}_{3}\left(\mathrm{H}_{3}\right) * \mathrm{~K}_{3}\left(\mathrm{H}_{3}\right)=3,55 * 10^{-3} * \\
0,01036 * 0,0372=2,4 * 10^{-6} \text { чол / piк. }
\end{gathered}
$$

\section{Висновки і перспективи подальших досліджень.}

Для підвищення обгрунтованості рішень 3 упереджуючого реагування на техногенну небезпеку потрібно завчасно оцінювати ризики життедіяльності від можливих аварій 3 урахуванням взаємодії техногенних і природних чинників, зумовлених проявами НЕГП як у межах промислових майданчиків, так i в зонах можливого впливу викидів небезпечних хімічних речовин. Це зумовлює необхідність в умовах особливого періоду у місцях розташування ХHO досліджувати i враховувати небезпеку прояву НЕГП.

К.: ІПНБ, 2005. - № 11. - С. 95-101.6 Качинський А.Б. Безпека, загрози і ризик: наукові моделі та математичні методи. - К.: ІПНБ, НАСБУ, 2004.- 472 с. 7.Наказ іністерства 3 питань надзвичайних ситуацій та у справах захисту населення від наслідків Чорнобильської катастрофи, Міністерства агаграрної політики, Міністерства економіки, Міністерства екології і природних ресурсів №73/82/64/122 від 27 березня 2001 року "Про затвердження Методики прогнозування наслідків впливу (викиду) небезпечних хімічних речовин при ававаріях на промислових об'єктах i транспорті". 8 Мушик Э., Мюллер П. Методы принятия технических решений. - М.: Мир, 1990. - 206 с.

\title{
ОЦЕНИВАНИЕ РИСКОВ ЖИЗНЕДЕЯТЕЛЬНОСТИ ЛЮДЕЙ В ПРИРОДНО-ТЕХНОГЕННОЙ СРЕДЕ В УСЛОВИЯХ ОСОБОГО ПЕРИОДА
}

\author{
Николай Николаевич Быченок (доктор технических наук, с.н.с.)
}

\section{Национальный университет обороны Украины имени Ивана Черняховского, Киев, Украина}

Возростание антропогенного воздействия на окружающую среду вместе с интенсивным использованием природных ресурсов вызывают устойчивую тенденцию к увеличению негативных последствий для жизнедеятельности населения от чрезвычайных ситуаций природного и техногенного происхождения на территории Украины. Кроме того, в неблагоприятных экономических условиях, а также гибридной войны на востоке Украины со стороны РФ, снижается уровень технологической дисииплины,уменьшаются затраты на внедрение новейших технологий, модернизацию производственных процессов і ремонтно-профилактические мероприятия, возрастает количество изношеннсго оборудования.

В даной работе на основе обобщения опыта оченивания и прогнозирования рисков возникновения чрезвычайных ситуаций в разных регионах Украины, в первую очередь на территориях повишенной природной и техногенной опасности, разрабатываются методологические основы оценки рисков жизнедеятельности в етих условиях.

Ключевые слова: чрезвычайные ситуации, риски жизнедеятельности, техногенные и природные угрозы. 


\title{
EVALUATION RISKS OF LIVE ACTIVITY OF PEOPLE IN NATURAL AND TECHNOGENIC ENVIRONMENT IN CONDITIONS OF SPECIAL PERIOD
}

\author{
Mikola Bychenok (Doctor of Technical Science, Senior Research Fellow)
}

\author{
National Defense University of Ukraine named after Ivan Cherniakhovsky, Kyiv, Ukraine
}

The increase in anthropogenic impact on the environment, together with the intensive use of natural resources, cause a steady tendency to increase the negative consequences for the life of the population from emergencies of natural and man-made origin in Ukraine. In addition, in adverse economic conditions, as well as a hybrid war in eastern Ukraine from the Russian Federation, the level of technological discipline is reduced, the costs of introducing the latest technologies, modernizing production processes and repair and maintenance measures are decreasing, and the number of worn-out equipment is increasing.

In this work, based on a generalization of the experience of assessing and predicting the risks of emergencies in different regions of Ukraine, primarily in areas of high natural and man-made danger, methodological foundations for assessing the risks of life in these conditions are developed.

Key words: emergency situations, life risks, man-made and natural threats.

\section{References}

1.Danilishin B.M. Natural-technogenic catastrophes: problems of economical analyses and control K.:NICHLAVA, 2001. - 260 p. 2.Bychenok M.M., Ivanjta S.P., Yakovlev Y.A. About influence of exogenic geological process on level tehnogenic risk of live activity// Collection of scientific works of UkrDIGRI 2006 №1.C..85-91 3.Buravlov E.P., Getman V.V. Control of technogenic safety - K.: IPNB , 2006. - 248 p. 4.National Report about state of technogenic and natural safety in Ukraine in 2006 y. - K. : DP «Chernobylinterinform», 2007. - 236 p.5.Ivanjta S.P. GIS realization of estimation risk of life activity from accidents on chemical dangerous objects : // Ecologic and resourses - K.: IPNB, 2005. № 11. - P.95-
101. 6.Kachynsky A.B Safety, threats and risk :csientific models and mathematical methods K.: IPNB, NASBU, 2004.-.472c.7.Order of Ministry from questions of extraordinary situations and defence of population from consequences of Chernobyl catastrophe, Ministry of agrarian politics, Ministry of economic, Ministry of ecologic and natural resources № 73/82/64/122 from 27 March 2001 year «About confirmation of metodic prognouzing consequences influence (throuw out) dangerously chemical substance in the time accidenns on industrial objects and transport. 8.Muschik E., Muller P. Methods of technic decides - M.: Universe, 1990.-206 p. 